\title{
Heuristic Framework for Sustainable Cooling Water Systems Operations in Oil Facilities
}

\author{
Hashim K.M. ${ }^{1}$, Hassim Mimi H. ${ }^{*}$ and Ng D.K.S. ${ }^{2}$ \\ ${ }^{1}$ School of Chemical and Energy Engineering / Centre of Hydrogen Energy, University Teknologi Malaysia, 81310 UTM \\ Johor Bahru, Malaysia \\ ${ }^{2}$ School of Engineering and Physical Sciences, Heriot-Watt University, No. 1, Jalan Venna P5/2, Precinct 5, 62200 \\ Putrajaya Malaysia
}

\begin{abstract}
To meet the growing demand for cleaner environment from the society, most leading oil companies have committed to preserve environment via reduction of greenhouse gases, water and soil pollution as well as the use of natural resources. In most of the oil facilities, they required massive cooling systems to cool down process streams in order to meet the process requirements. The most common cooling system in oil facilities is evaporative cooling water system (ECWS) as such system has high efficiency. Cooling water is commonly used in offices and residential areas. However, the cooling water system is one of the utility systems that generates high environmental impacts due to high consumption of power, water and chemicals. Therefore, it is important to optimize the system in the early design stage of the project to operate in the most effective and efficient condition. In reality, many efforts may be missed out due to loose project definition, inexperience design engineer, hectic project schedule, or resource constraint. Therefore, in order to overcome the previous limitations, this paper presents a comprehensive heuristic improvement framework for cooling water systems in oil operating facilities.
\end{abstract}

Keywords: cooling water system; cooling performance; cooling water design; utility improvement initiatives; heuristic framework

\section{INTRODUCTION}

Many oil companies are struggling to maintain a competitive edge in the modern global economy (IPIECA, 2013). Despite focusing on increasing profitability from its operations, most of oil companies are also committed to high expectations on environmental performance and social obligations (Worell et al., 2006). As outcomes from Conference of the Parties (COP) 21 (Worland, 2015), oil companies are expected to reduce pollutants, especially greenhouse gases (GHG), solids and effluents wastes, minimize the use of natural resources and eliminate the use of hazardous chemicals.

According to The National (2015), many countries especially major oil producers such as Saudi Arabia, Kuwait, Bahrain, Oman, Venezuela, Iran and Russia are suffering to manage budget deficit due to high subsidies on energy during high crude oil price. On the other hand, during the period of low crude oil price, it is also impacted significantly most of those countries that highly depending on oil revenue. The evidence showed that endorsing stringent environmental policies will cause an adverse impact to companies' profitability (Carrato, 2017). Compliance costs will increase and shift pollution-intensive production towards low abatement cost regions and countries. In the long run, it will negatively affect the economic growth of the concerned countries.

Opportunities for cost reductions exist in certain water management areas such as effluent treatment plant, cooling water systems, power and chemicals usage (Hashim, 2004). Since water management cost in many oil facilities has significantly contributed to total production cost, any attempt to reduce such cost will improve the financial performance of the company. 
Cooling systems are the most common cooling utility facility which produces cooling water to cool down process streams and process units (Bahadori, 2016). The availability of water and its high heat capacity has made water the most preferred heat transfer medium in industrial and nonindustrial applications. Direct air-cooling system is the simplest cooling system, however, it is not as productive as water due to the limitation in meeting process requirements and environmental constraints. For closed-loop cooling water system, it is only suitable for small system due to high operating cost (Bahadori, 2016). In many cases, it relies solely on ambient air to cool the working fluid to near dry-bulk temperature.

The evaporative cooling water system (ECWS) uses a cooling tower as a heat rejection device using the evaporation method (Betz Industrial, 1989). ECWS is an efficient and cost-effective method that cools the working fluid near to the wet-bulb temperature, which is always lower than the dry bulb temperature. ECWS is the most preferable as it can reduce the impact of water withdraw rate by over $90 \%$ compared to the once-through cooling water system (Betz Industrial, 1989). Unlike once-through cooling where heat is being dissipated to a water receiving body, ECWS rejects collected heat load to the environment through evaporation. Furthermore, with stringent effluent discharge limits as imposed by the World Bank (Liu et al., 1996; General EHS Guideline, 2020) have made once-through cooling is unfavourable due to highly anticipated capital expenditure (CAPEX) and operating expenditure (OPEX) (Freedman, 2004).

Although cooling water systems have played an important role in oil industry, however, optimizing cooling water systems has not been prioritized in the past (Freedman et al., 2004). According to the study (Freedman et al., 2004) conducted by a major oil facility in early 2000, on 332 heat exchanger failures over the past 3 year period, it was discovered that these failures resulted in nearly \$50 million of loses, both in direct maintenance and loss in profit. Meanwhile, in another study (Prasad et al., 2005), a team from Pacific Northwest Laboratory estimated, in between 1984 to 1985 that heat exchanger fouling problems mainly caused by cooling water operations and cost United States (US) industries of $\$ 4$ to $\$ 10$ billion per year. The biggest cost contributors are production losses, asset utilization, energy, and maintenance cost. Despite energy, cooling water systems are usually one of the major water users in oil operating facilities. These systems can be potential sources of pollutant discharge to the environment through blowdown. Cooling water normally contains dosed chemicals during the treatment process. Without a dedicated monitoring program for the blowdown stream, it may also potentially cause pollution to the environment (Lattemann et al., 2007).

Cooling water operation can affect productivity, operating costs, reliability and environmental impacts (Bahadori, 2016). Several obstacles have been identified such as lack of focus during the design stage, operational limitation, competency of the operational team, selection of treatment program, performance monitoring as well as poor make-up water quality (Carrato, 2017; Bahadori, 2016; Betz Indusrial, 1989; Freedman et al., 2004). As per old paradigm the term "cooling water" always stands out as "must have" without needs for improvement. In current competitive world, improvement is an important sustainable measure for cooling water system operators. Activities such as minimizing operational downtime and the optimum used of natural resources are keys to success (Worell et al., 2006). It can be expedited by improving productivity, flexibility, reliability and efficiency with technology-based services throughout the lifecycle of industrial facilities (Capehart et al., 2012).

Developing a structured improvement mechanism enable to improve the cooling water performance in meeting stringent goals. For many oil companies, sustainability measures that deliver savings or reduce environmental impacts from cooling water optimizations have not been well defined. According to Zandi and Nava (2019), greater value can be identified through a wider cooling water study scope. In current economic slowdown, a competitive business environment, limited conventional natural resources, made these optimized cooling water approaches difficult to be executed.

This paper presents a comprehensive heuristic framework for cooling water systems in operating facilities within oil companies. It covers the key concepts of the cooling water systems and its applications, flow control, user management, heat load calculation, overall performance improvement and savings opportunities. It also identifies an optimum cooling 
medium to be used for different applications. Inappropriate selection of cooling systems may cause complications in maintaining the integrity of the said facilities. Having a dedicated framework to explore improvement opportunities including new efficient equipment, new technology, new processes and approaches, shall be prioritised. Note that involvement in early project stages is important to ensure cooling systems efficiency concepts will be considered.

This paper is structured as follows. Different configurations of cooling water systems are first introduced. Next, the method to measure the performance of cooling water systems is discussed. It follows by the presentation of the systematic approaches embedded within the proposed heuristic framework to enhance cooling systems performance. Finally, the paper will discuss proven improvement initiatives and several successful case studies to lead for a total overhaul of the cooling water systems.

\section{A. Cooling Water Systems}

The main objective of cooling water systems is to produce a cooling medium for receiving heat from processes and reject it to other mediums (Bahadori, 2016). Focusing on ECWS or open recirculation cooling water system, a cooling tower is served as a rejection device which releases waste heat to the atmosphere through the cooling off working fluid (water) by means of evaporation. Evaporation of water allows a small portion of water molecule to evaporate into a moving air stream to provide a cooling effect to the rest of the water stream. The heat from the water stream transferred to the air stream pushes the air's temperature, and its relative humidity to $100 \%$ and this air is then removed to the atmosphere. A brief illustration of the basic diagram of the ECWS is shown in Figure 1. To avoid contaminant accumulation in the close loop cooling water system, blow down is commonly required in such a system. Due to the losses of water during the evaporation process and blowdown, make up water is supplied to the cooling down to replace the losses of water.

Fouling and corrosion are two important operational problems in cooling water, especially the ECWS (Betz Industial, 1989). The mentioned problems dictate a suitable operating philosophy for the ECWS. If the cooling water has reached to the unacceptable bacteria levels or an elevated content of suspended solids or organic components, there is a potential risk of corrosion (Bahadori, 2016). Such substances can foul the surfaces of heat exchangers. Fouling will increase the pressure drop in the system and lead to higher power consumption (Freedman et al., 2004). As mentioned previously, solids deposits in the system caused by both chemical precipitates and particulate material from air entrapped into the water in the cooling tower serve as the carrier material for bacterial growth.

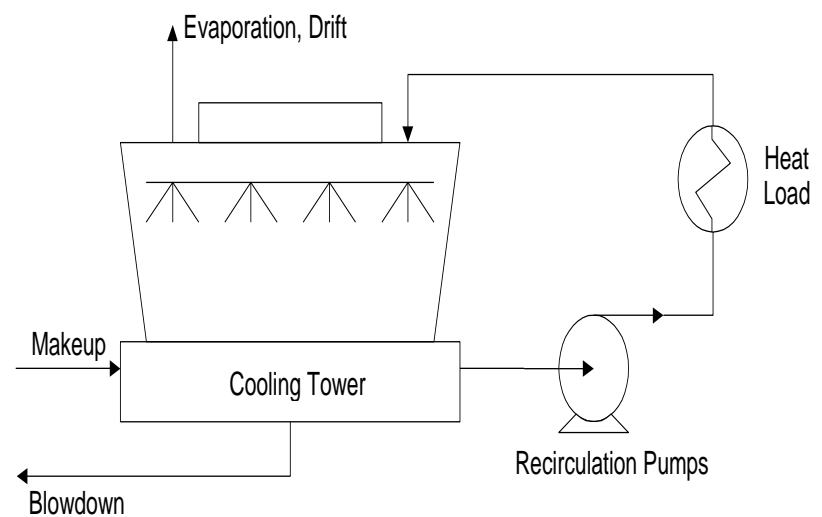

Figure 1. ECWS diagram

Besides focusing on corrosion and fouling issues, typical installations and features of ECWS also addresses health, and safety and environment (HSE) aspects, ensure the reliability of cooling water supply and low OPEX (Bahadori, 2016; Betz Indusrial, 1989; Freedman et al., 2004):

- Cooling tower type, natural, induced or forced draft with either cross-flow or counter-flow. Depending on the process and design requirements, an induced cooling tower is commonly found in the oil facilities.

- Cooling tower components e.g., such as tower water sump (basin) for which water is drawn and circulated to the system, circulation pumps, and screens on the pump intake sump to prevent objects from causing damage to the circulations pumps, plugging the heat exchangers and cooling water return distribution nozzles.

- Side stream filter is used to remove debris and particles that affect cooling performance.

- Dosing skid, where treatment chemicals are prepared and injected into cooling water systems.

- Water inlet to replenish the water loss mainly by evaporation (make-up water).

- Blowdown to bleed some portion of circulated water prior to controlling salts content.

- Monitoring devices, including flow meters, power meters, start/stop indicators, temperature probes, and level transmitters and analyzer for critical parameters. 
Cooling water systems require dedicated operational and maintenance programs to keep it reliable and efficient (Freedman et al., 2004). With periodic inspection, a good maintenance program, and comprehensive operational philosophy, even an old facility can still remain efficient and reliable (Richardson, 2014). To keep facilities running efficiently, the utility engineers must continue to improve and identify potential improvement initiatives, and implement such initiatives as soon as possible. Utility engineers shall regularly assess facility conditions and identify execution strategies, to sustain its efficient operation.

\section{B. Performance Monitoring of Cooling Water System}

Sustaining the efficient operation of cooling water system is very important task of utility crew. Therefore, performance of such system needs to be evaluated regularly (Lindberg et al., 2015). Factors that can influence the cooling tower's performance and should be considered when choosing a cooling tower: capacity, range, approach, heat load, wet bulb temperature, and the relationship between these factors (Bahadori, 2016).

According to Kemmer (1987), cooling tower efficiency (E) can be calculated using Equation 1. An overall cooling system performance (OP) can be measured via Equation 2. Meanwhile, heat exchanger heat load (HL) will be calculated through Equation 3 .

$$
\begin{aligned}
\mathrm{E}= & \frac{\left(\mathrm{T}_{\text {Hot Water }}-\mathrm{T}_{\text {Cold water }}\right) \times 100}{\left(\mathrm{~T}_{\text {Hot Water }}-\mathrm{T}_{\text {Wet bulb }}\right)} \\
= & \Delta \mathrm{T} \times 100 /\left(\mathrm{T}_{\text {Hot Water }}-\mathrm{T}_{\text {Wet bulb }}\right)
\end{aligned}
$$

$\mathrm{OP}=\Delta \mathrm{T} \times \mathrm{Wcp} \times \mathrm{W} /$ Total power usage in $\mathrm{kWh} /$ day

$\mathrm{HL}=\Delta \mathrm{T}$ (water inlet and outlet heat exchanger) $\mathrm{x}$ Wcp $\mathrm{xW}$

$=\Delta \mathrm{T}$ (process inlet and outlet temperature) $\times$ Pcp $\times \mathrm{P}$

$=\mathrm{U} \times \mathrm{A} \times \Delta \mathrm{Tm}$

Notes;

$$
\begin{aligned}
& \mathrm{E}=\text { Cooling tower efficiency in } \% \\
& \mathrm{~T}=\text { Temperature in }{ }^{\circ} \mathrm{F} \\
& \text { WCp }=\text { Water specific heat capacity in } \mathrm{BTU} /{ }^{\circ} \mathrm{F} / \mathrm{lb} \\
& \mathrm{PCp}=\text { Process specific heat capacity in } \mathrm{BTU} /{ }^{\circ} \mathrm{F} / \mathrm{lb} \\
& \mathrm{OP}=\text { Overall cooling system performance }(\mathrm{BTU} / \mathrm{kWh}) \\
& \mathrm{HL}=\text { Heat exchanger heat load in Btu } / \mathrm{h}
\end{aligned}
$$

$\mathrm{W}=$ Water mass flow rate in $\mathrm{Ib} /$ day

$\mathrm{P}=$ Process mass flow rate in $\mathrm{Ib} /$ day

$\mathrm{A}=$ Area in feet square

$\mathrm{U}=$ Overall heat coefficient in $\mathrm{BTU} /\left(\mathrm{hr}-\mathrm{ft}^{2}{ }^{\circ} \mathrm{F}\right)$

$\Delta \mathrm{Tm}=\mathrm{Log}$ mean temperature by the following equation:

$$
\ln \frac{\Delta \mathrm{Tm} 1-\Delta \mathrm{T}_{2}}{\left.\Delta \mathrm{T}_{1} / \Delta \mathrm{T}_{2}\right]}
$$

Where $\Delta \mathrm{T} 1$ and $\Delta \mathrm{T} 2$ are the temperature difference between the cooling water and process streams, respectively.

Note that other important tracking or leading ECWS performance measures are listed in Table 1 (Freedman et al., 2004). Brief descriptions of the possible impacts are also included.

Table 1. Tracking and leading measures (Freedman et al., 2004)

\begin{tabular}{ll}
\hline \multicolumn{1}{c}{ Measures } & \multicolumn{2}{c}{ Impact } \\
\hline Heat exchanger & - Efficient hear transfer \\
cleanliness & performance. \\
& - Low cooling system pressure \\
& drop to reduce power usage. \\
Control of corrosion & - Improve plant reliability. \\
& - Reduce maintenance cost. \\
& - Minimize cooling water usage \\
& by maintaining high cycle of \\
& concentration.
\end{tabular}

Mineral scaling

- Reduce scaling potential on heat exchangers.

- Sustain heat transfer performance.

General deposition

- Reduce micro organization growth.

- Minimize fouling.

Microbiological - Contribute for exchanger growth fouling.

- Reduce corrosion risk.

\section{MATERIALS AND METHOD}

Figure 2 provides a methodology that will be used to accomplish this study. It is started with defining the objectives of study. It this case, the main objective is to establish a heuristic framework for sustainable cooling water systems operations in concerned oil companies. Some contents of the study will be based on proven approaches by 
one of leading oil company located in Malaysia' Gebeng Industrial Estates. This company owns and operates large EWCS in order to fulfil the cooling requirement from its petrochemical plant. It is not the intention of the paper to conduct EWCS performance comparison due to the confidentiality of some information.

The sustainable operations are defined as no harm to people, no damage to the environment, low OPEX and reliable service. The next stage of study is to review applicable references, e.g., industry best-practices, case studies, books, journals and related articles. Subsequently, relevant information will be used to determine the most effective approaches and initiatives to enhance the cooling water system performance.

It follows the third stage of confirming the applicability of identified improvement approaches and initiatives to meet defined criteria, e.g., OPEX, HSE and reliability. The following stage is site experience through improvement assessment, equipment verification and pilot test. Finally, the heuristic framework for cooling water systems improvement can be concluded and will be presented in the following sections. The establishment of framework with a focus on proven initiatives implemented in concerned oil companies and also five case studies.

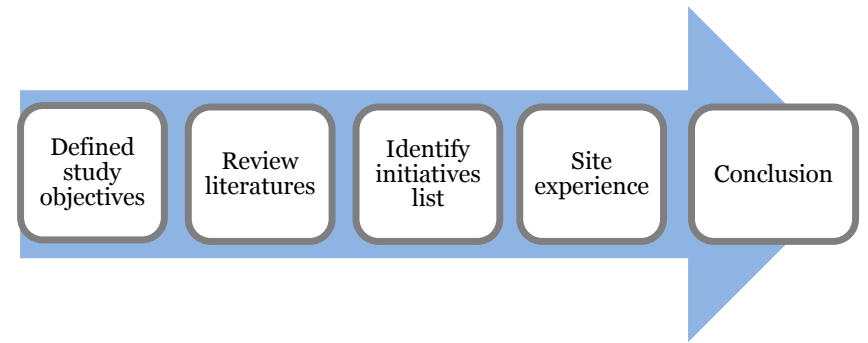

Figure 2. Cooling water improvement steps

\section{RESULT AND DISCUSSION}

The following sub-titles will describe the detailed steps and sub-steps to establish systematic heuristic cooling water systems improvement framework for respective oil companies.

\section{A. Define Study Objective of Sustainable Cooling Water Systems Operations}

In order to achieve the study objective for sustainable cooling water systems operations, a systematic heuristic framework is required (IPIECA, 2013). In reference to relevant literature (Hashim et al., 2018), five main steps have been considered prior to establish the improvement framework for cooling water systems. The five steps are; gaining management commitment, form an improvement team, define improvement plan, execute identified actions and evaluate achievement, which mirrors Deming quality circle of Plan, Do, Check and Adjust (Pyzdek \& Keller, 2013). As illustrated in Figure 3, each step will be supported by several sub-steps to provide more coverage of the required activities toward strengthening the intent of the framework.

It follows by a formation of an improvement team which involves the appointment of competent members from multiple disciplines e.g., technical, operations as well as a maintenance representatives. A dedicated team led by a competent utility engineer should be fully engaged to gather their commitment to meet the desired objectives and targets.

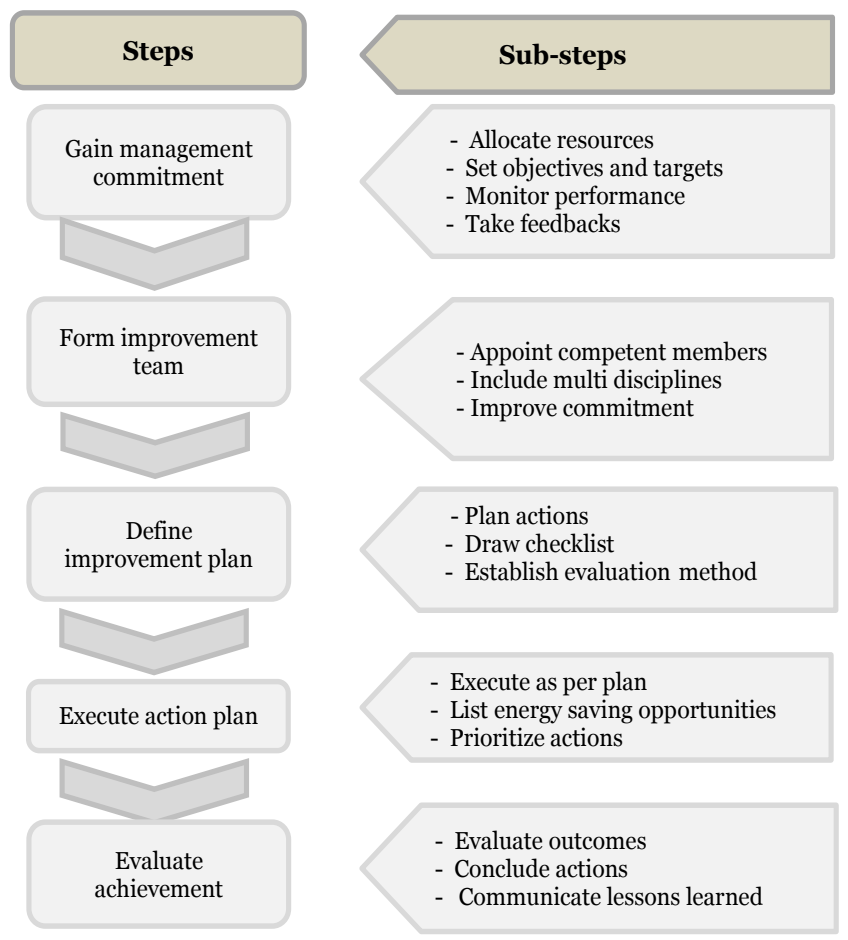

Figure 3. Heuristic framework for cooling water systems improvement

The improvement plan or scope can be defined in line with agreed objectives and targets. In this step (define improvement plan), the team shall develop a comprehensive checklist as defined scope to simplify the process to gather improvement initiatives as well as to establish systematic 
evaluation method. Recommended evaluation methods are listed in Table 2 (Hashim et al., 2018).

In the execute action plan, dedicated task is taking place to capture identified initiatives from the previous step. It follows by assessing and prioritizing identified initiatives that will be discussed in the next Section. Therefore, the implementation of any accepted initiative will be planned in due course and discussed in next Section.

Table 2. Initiative evaluation criteria (Hashim et al., 2018)

\begin{tabular}{|c|c|}
\hline Criteria & Rationale \\
\hline Technical evaluation & Ensure technically acceptable. \\
\hline $\begin{array}{l}\text { Operational } \\
\text { evaluation }\end{array}$ & Easy to be implemented. \\
\hline Simple Risk Analysis & $\begin{array}{l}\text { Conduct strength, weakness, } \\
\text { opportunity and threat. }\end{array}$ \\
\hline Incentives & $\begin{array}{l}\text { Economic, HSE improvement, } \\
\text { water and energy-saving, and } \\
\text { GHG reduction. }\end{array}$ \\
\hline Process & Identify the need for \\
\hline $\begin{array}{l}\text { Management (PSM) } \\
\text { review }\end{array}$ & $\begin{array}{l}\text { management of change, hazard } \\
\text { and operability study (HAZOP) }\end{array}$ \\
\hline & $\begin{array}{l}\text { review and other specific } \\
\text { requirements each applicable } \\
\text { company. }\end{array}$ \\
\hline Other information & $\begin{array}{l}\text { Decision making and path } \\
\text { forward plan. }\end{array}$ \\
\hline
\end{tabular}

In the last step of evaluating achievement, each of the implemented initiatives shall be closely monitored and evaluated, to confirm its effectiveness. Feedbacks and lessons learned captured during the implementation shall be used to enhance the framework further. In general, the framework shall be kept simple and flexible, which the main focus is to drive for efficient and reliable cooling water systems.

\section{B. Execution of the Cooling Water Systems Improvement Framework}

Grossmann and Fuman (2013) highlighted that major improvement items include planning, scheduling, real-time performance monitoring and inventory control. As a critical task identified in the framework, concerned companies shall focus on identification of applicable improvement opportunities from published literatures and lessons learned. Subsequently, the team shall proceed to evaluate and implement each identified opportunity as per the agreed time frame. Oil companies are required to undertake rigorous and comprehensive efforts to optimize their cooling water performance by using the effective and structured operational approaches, or framework (Freedman et al., 2004).

After establishing the heuristic framework, initial improvement assessment can be conducted through table top exercises and site visits. Depth of the assessment details shall reflect factors listed in Table 3. In addition, it can include reviews on previous assessment findings, progress already made, coincidence with maintenance outage of equipment, structural opportunities, and other minor factors.

Table 3. Cooling water systems assessment factors

\begin{tabular}{|c|c|}
\hline Factor & Obstacle \\
\hline Age of facilities & $\begin{array}{l}\text { Technology and } \\
\text { limitation. }\end{array}$ \\
\hline $\begin{array}{l}\text { Statutory } \\
\text { requirements } \\
\text { and company } \\
\text { standards }\end{array}$ & $\begin{array}{l}\text { Effluent discharge limit, air } \\
\text { emissions regulation, limitation on } \\
\text { the use of certain treatment } \\
\text { chemicals, cooling water velocity and } \\
\text { water conservation limit. }\end{array}$ \\
\hline $\begin{array}{l}\text { Process } \\
\text { requirement }\end{array}$ & $\begin{array}{l}\text { Process cooling requirement, } \\
\text { construction material (metallurgy), } \\
\text { process fluid, elevation. }\end{array}$ \\
\hline Water & $\begin{array}{l}\text { Quality of supply water, pricing and } \\
\text { supply reliability. }\end{array}$ \\
\hline Energy & Source of energy and price. \\
\hline Location & $\begin{array}{l}\text { Location of operating facility, } \\
\text { ambient conditions and siting of } \\
\text { cooling tower. }\end{array}$ \\
\hline
\end{tabular}

As indicated by Teicholz (2001), the conducting systematic and routine improvement assessment on cooling water systems can identify the deficiency in its overall performance. Additional assessment purposes include:

- To define the types and cost associated with cooling water systems operation.

- To identify how energy, water and chemicals are being used or wasted.

- To define "big picture" and therefore identify focused items.

- To identify and analyze alternatives such as improved operational technique and/or new equipment that can 
significantly minimize the use of natural resources and improve performance.

- To perform an economic analysis on these alternatives and determine which are cost-effective.

- To understand current obstacles and constraints for both process units and cooling water systems.

- To determine future cooling water systems improvement assessment approaches and frequency

Typical information required prior to conduct a comprehensive cooling water systems assessment is listed in Table 4. Prior to the initial assessment, the appointed competence utility engineer shall establish the relevant checklist to ensure all required tasks listed in Table 4 are covered. Comprehensive improvement assessment involves data collection and analysis, opportunities identification and evaluation, the decision-making process, and implementation planning.

Table 4. Typical information required

\begin{tabular}{|c|c|}
\hline Type of information & Rational \\
\hline $\begin{array}{l}\text { Process and cooling water } \\
\text { systems description. } \\
\text { Cooling water systems flow } \\
\text { diagram and facility layout. }\end{array}$ & $\begin{array}{l}\text { Understand process } \\
\text { requirements and users. } \\
\text { Cooling water maps. }\end{array}$ \\
\hline $\begin{array}{l}\text { Geographic location and } \\
\text { weather data. }\end{array}$ & $\begin{array}{l}\text { Require for performance } \\
\text { and design calculation. }\end{array}$ \\
\hline $\begin{array}{l}\text { Operational data (from } \\
\text { process data, measurements, } \\
\text { treatment packages and } \\
\text { invoicing). }\end{array}$ & $\begin{array}{l}\text { Conduct performance } \\
\text { calculation, chemical } \\
\text { treatment program, cost, } \\
\text { treatment performance }\end{array}$ \\
\hline & $\begin{array}{l}\text { and environmental } \\
\text { performance. }\end{array}$ \\
\hline Plant reliability data. & $\begin{array}{l}\text { Status of heat exchangers } \\
\text { fouling and corrosion } \\
\text { condition. }\end{array}$ \\
\hline $\begin{array}{l}\text { Price of energy, water and } \\
\text { chemicals and respective } \\
\text { contract document. }\end{array}$ & $\begin{array}{l}\text { Calculate cost of cooling } \\
\text { water. }\end{array}$ \\
\hline $\begin{array}{l}\text { Environment requirements } \\
\text { e.g., effluent discharge, air } \\
\text { pollution and banned } \\
\text { chemical list. }\end{array}$ & $\begin{array}{l}\text { Define limitation and } \\
\text { constraint. }\end{array}$ \\
\hline $\begin{array}{l}\text { Related internal engineering } \\
\text { standards. }\end{array}$ & $\begin{array}{l}\text { Define limitation and } \\
\text { constraint. }\end{array}$ \\
\hline
\end{tabular}

\begin{tabular}{lrl}
\hline $\begin{array}{l}\text { Previous assessment } \\
\text { study reports. }\end{array}$ & and & $\begin{array}{l}\text { Understand the } \\
\text { outstanding and status of } \\
\\
\end{array}$ \\
& implementation.
\end{tabular}

All potential improvement opportunities identified during the assessment review, interviews and walk-throughs have to be listed for further evaluation. Similarly, the identified focus items are also been identified after being carefully reviewed to determine where improvement can be achieved. The recommended selection criteria has been discussed in Table 2, such as conducting economic, technical and operational and HSE evaluation. These reviews shall be led by competence utility engineer, who possess a good knowledge of the current cooling water efficiency technologies and best practices.

Identifying the comprehensive findings that can be concluded to address agreed improvement intents, including the list of challenges, mitigations, and future paths. Subsequently, a list of improvement opportunities shall be concluded with detailed action plans. As recommended by ISO 50001 (2018), action plans should include;

- Responsibilities designation.

- The means and time frame by which individual targets are to be achieved.

- A statement of the method by which an improvement in cooling water performance can be verified.

- Statement of method of verifying the results.

After the completion of assessment and following hand over of action plans to assignees, it is important to monitor its implementation status to ensure all actions are completed as intended. The implementation approaches and outcomes may vary from the initial plans. There may be minor adjustments to set points, maintenance schemes or control strategies that can provide better cooling water system performance.

\section{Execution of the Cooling Water Systems Improvement Framework}

According to Turner (2011), operation, maintenance and technical teams acted as the main contributor for main successful of any improvement framework. Properly maintained equipment and processes are necessary to keep 
the facility at the optimum capability. It is a major focus for oil facilities after HSE issues to fulfil its required production target. A utility in particular cooling water systems often comes a poor second. Changes in one process or piece of hardware can cause a cascade hard to unforeseen consequences. Some may improve cooling water use, but others may have a negative impact on cooling water demand.

Comprehensive operating philosophies include the following: reduce the use of cooling tower fans during the cold season, operate cooling water circulation at optimum load, fix all process and utilities leaks, and other activities that can improve cooling water systems performance (Turner, 2001). Operators can be made responsible for improvement efforts that they can influence. Any conflicts with margin value can be dealt, e.g., the daily variability and daily disturbance that every facility encounters. Similarly, according to the researcher, maintenance measures are also essential, particularly on each identified cooling water user, including monitoring equipment performance, initiating preventive maintenance programs, and fixing any equipment deficiency within acceptable duration (Bloch, 2016).

With good coordination between team members of improvement and other supporting entities, the cooling water improvement idea can be effectively explored. At the start, each respective employee is expected to list all possible cooling water improvement options, required actions or necessary modifications to achieve the specified or desired process targets and to optimize users, equipment, utility systems or new designs to fulfill the agreed targets. The improvement of specific process units or equipment can be iterated to achieve the integration between process and utility components e.g.; both designs should complement each other instead of considering two isolated systems. This approach includes identification of all related operational activities in a minimum possible time using provided process data and without any interruption to the overall operations.

Ranging in cost and complexity from walkthroughs to detailed assessments, the collection and analysis of data formed the foundation for prioritizing improvement opportunities. Outcomes from cooling water assessment include:

- List of potential cooling water users based on substantial cooling load.
- Variables affecting the identified users.

- Analysis of the current performance of the users,

- Estimation of future cooling load and consumption.

Opportunities for improvement begin with the ideas that can be generated from the analysis of cooling demand and consumption, the determination of cooling load big picture, or from a variety of other sources. The involvement of operational and maintenance staff along the process can be useful in revealing a full range of ideas. These ideas become opportunities through examination and refinement by using data analysis. It will follow by defining potential initiatives to improve cooling water performance improvement. Identification of opportunities for improvement in an ECWS performance should be part of a continuous improvement process. It may also involve a periodic analysis using proven techniques by competent utility engineers.

Tools and techniques for identifying improvement opportunities as recommended by Kaufman (2012) may include the followings:

- Employee suggestions.

- Team meetings, brainstorming and opportunity identification workshops.

- Cooling water networks, seminars, forums, conferences to exchange ideas and experiences

- Business improvement methodologies such as Lean Manufacturing, Six Sigma or Kaizen.

- Analysis to avoid inappropriate design decisions.

- Internal or external benchmarking.

- Equipment specifications and data sheets.

- Maintenance techniques such as condition monitoring or predictive maintenance.

- Review of new and emerging technologies.

- Lessons learned from applicable case studies.

- Opportunity lists and cooling water improvement tips from company websites.

- Engineering analysis techniques and modeling such as review of pump operating systems curves, energy and water pinch analysis.

- Treatment vendor's proposal.

Currently, the scope of cooling water improvement assessment includes power, water heating and cooling 
systems required to satisfy certain process demands. As indicated by Kaufman (2012), the above list shall be considered to enhance the effectiveness of an initial cooling water improvement assessment. It will encourage more effective improvement ideas by the respective oil companies with a comprehensive user-friendly methodology.

The theme of this quick cooling water improvement methodology in accordance with Turner (Turner, 2011) for energy efficiency improvement can be followed. Cooling water assessments may be primitive or comprehensive. A variety of approaches, methods and tools are available to conduct such "energy balance" and "water balance" to improve the cooling water efficiency of industrial processes.

Monitoring is an essential part of any effective improvement step (Hansen \& Brown, 2003). There is no way to confirm whether the cooling water is effective or the improvement measures are delivering as expected without monitoring. According to the Australian Government (2013), a comprehensive monitoring program involves estimation, evaluation, measurement and tracking of cooling water efficiency opportunities and implementation progress. The effective monitoring program starts with the establishment of simplified methodologies. It shall consist of structured data collection, robust analyses and evaluations to enhance decision making processes in defining challenging objectives and targets, and resources planning. Monitoring program may vary for each company. The program can range from simple monitoring campaigns such as analysis of an electricity bill to a very complex one that requires an advanced on-line data collection, verification, meter calibration, analysis, and performance reporting.

It is indicated that monitoring of utilities consumption for facilities, systems, processes, and equipment is an initial step that includes:

- Efficiency tracking program (Lindberg et al., 2015).

- Cooling water and heat exchangers' heat and water balance (Freedman et al., 2004).

- Cooling tower performance (Kemmer, 1987)

- Pump and fan efficiency calculation (Hashim et al., 2018).

- Heat exchangers fouling monitoring campaign (Freedman et al., 2004).

- Equipment load management (Hashim, 2004).

\section{Execution of the Cooling Water Systems Improvement Framework}

There are many initiatives that have been successfully implemented to improve the ECWS performance either through low hanging fruit initiatives (LH), quick fix (QF) for nominal or with major investment (MI) (Hashim et al., 2004).

Table 5 provides a basic magnitude of savings for the last three categories (Hashim et al., 2004)

Table 5. Typical initiative categories (Hashim et al., 2004)

Approach Potential

Savings

\begin{tabular}{ll}
\hline Operational improvement or "low & $<15 \%$ \\
hanging fruits" saving initiatives (LH) & \\
Low cost "Quick Fix" initiatives (QF) & $<35 \%$ \\
Higher cost initiatives with CAPEX (MI) & $<50 \%$ \\
\hline
\end{tabular}

Typical and widely accepted cooling water systems improvement initiatives are listed in Table 6. These initiatives are preliminary and based on successful implementation at several facilities within concerned oil companies. In this paper, some detailed evaluations were conducted and summarized in the case studies for the successful cooling water improvement study. The studies are discussed in next sections.

Table 6. List of typical saving opportunities

\begin{tabular}{|c|c|c|}
\hline $\begin{array}{l}\text { Category of } \\
\text { initiatives } \\
\text { (LH/QF/MI) }\end{array}$ & Area of opportunity & $\begin{array}{c}\text { Impact } \\
\text { (savings) }\end{array}$ \\
\hline LH & $\begin{array}{ll}\text { Load } & \text { management for } \\
\text { cooling } & \text { water recirculation } \\
\text { pumps } & \text { (Capehart et al., } \\
\text { 2012). } & \end{array}$ & Power \\
\hline $\mathrm{LH}$ & $\begin{array}{l}\text { Monitor heat exchangers by } \\
\text { comprehensive measures } \\
\text { (Capehart et al., 2012). }\end{array}$ & $\begin{array}{l}\text { Power and } \\
\text { chemicals }\end{array}$ \\
\hline $\mathrm{LH}$ & $\begin{array}{l}\text { Cooling tower fans } \\
\text { minimization (Muller \& Roa, } \\
\text { 2013). }\end{array}$ & Power \\
\hline $\mathrm{LH}$ & $\begin{array}{l}\text { Operate cooling towers and } \\
\text { cooling systems at optimum } \\
\text { condition (Muller \& Roa, } \\
\text { 2013). }\end{array}$ & $\begin{array}{l}\text { Power and } \\
\text { chemicals }\end{array}$ \\
\hline
\end{tabular}




\begin{tabular}{|c|c|c|}
\hline $\mathrm{LH}$ & $\begin{array}{lr}\text { Minimize } & \text { water } \\
\text { consumption by increase } \\
\text { cooling cycles } \text { (Hashim, } \\
\text { 2004) }\end{array}$ & $\begin{array}{l}\text { Water, } \\
\text { chemicals } \\
\text { and power }\end{array}$ \\
\hline LH & $\begin{array}{l}\text { Conduct regular lab test for } \\
\text { critical parameters i.e., free } \\
\text { chlorine, phosphate, } \\
\text { bacteria count etc. (Betz } \\
\text { Industrial, 1989). }\end{array}$ & Chemicals \\
\hline LH & $\begin{array}{l}\text { Establish competency matrix } \\
\text { for utility engineers, } \\
\text { operation and maintenance } \\
\text { teams (Hashim et al., 2019). }\end{array}$ & $\begin{array}{l}\text { Water, } \\
\text { chemicals } \\
\text { and power }\end{array}$ \\
\hline $\mathrm{LH}$ & $\begin{array}{l}\text { On-line monitoring for } \\
\text { critical parameters, major } \\
\text { heat exchangers and } \\
\text { efficiency of cooling system } \\
\text { and tower in DCS (Muller \& } \\
\text { Roa, 2013). }\end{array}$ & $\begin{array}{l}\text { Water, } \\
\text { chemicals } \\
\text { and power }\end{array}$ \\
\hline $\mathrm{LH}$ & $\begin{array}{l}\text { Establish leading indicator } \\
\text { to track in cooling water } \\
\text { systems performance } \\
\text { (Hashim et al., 2019). }\end{array}$ & $\begin{array}{l}\text { Water, } \\
\text { chemicals } \\
\text { and power }\end{array}$ \\
\hline $\mathrm{QF}$ & $\begin{array}{l}\text { Apply suitable chemical } \\
\text { programs (Betz Industrial, } \\
\text { 1989). }\end{array}$ & $\begin{array}{l}\text { Water and } \\
\text { chemicals }\end{array}$ \\
\hline $\mathrm{QF}$ & $\begin{array}{l}\text { Eliminate hydrocarbon or } \\
\text { process leaks to cooling } \\
\text { water (Betz Industrial, } \\
\text { 1989). }\end{array}$ & $\begin{array}{l}\text { Water and } \\
\text { chemicals }\end{array}$ \\
\hline $\mathrm{QF}$ & $\begin{array}{l}\text { Conduct preventive } \\
\text { maintenance such as heat } \\
\text { exchangers cleaning and } \\
\text { rotating equipment typical } \\
\text { servicing (Richardson, } \\
\text { 2014). }\end{array}$ & $\begin{array}{l}\text { Chemicals } \\
\text { and power }\end{array}$ \\
\hline $\mathrm{QF}$ & $\begin{array}{l}\text { Removal of sludge sediment } \\
\text { from cooling tower basin } \\
\text { (Richardson, 2014). }\end{array}$ & Chemicals \\
\hline $\mathrm{QF}$ & $\begin{array}{l}\text { Fix cooling tower structure } \\
\text { damage, packing, louvres, } \\
\text { inlet nozzles (Freedman et } \\
\text { al., 2004). }\end{array}$ & $\begin{array}{l}\text { Water and } \\
\text { chemicals }\end{array}$ \\
\hline $\mathrm{QF}$ & $\begin{array}{l}\text { Install fouling and corrosion } \\
\text { monitoring coupons and } \\
\text { monitoring critical heat }\end{array}$ & $\begin{array}{l}\text { Water and } \\
\text { chemicals }\end{array}$ \\
\hline
\end{tabular}

\begin{tabular}{ll}
\hline exchanger $\quad$ performance \\
(Freedman et al., 2004).
\end{tabular}

\section{Case study 1 - Magnetic water conditioning}

This work intended to evaluate the effectiveness of magnetic water conditioning technology in removing certain scaling substances in the make-up water. The outcome from the study was intended to assist this anonymous company to overcome the recurrent scaling issues in heat exchangers (Freedman et al., 2004). It was a tabletop exercise based on available information captured from the US Department of Energy Federal Technology Alert: Non-Chemical Technologies for Scale and Hardness control (US Department of Environment, 2020) and other supported internal documents.

A non-chemical technology for scale and hardness control is nothing new. For example, magnetic technology has been cited in the literature and investigated since the beginning of the last century (Hashim, 2004). Today, advances in magnetic and electrostatic scale control technologies have led to the technology being a reliable energy saver in certain applications. The general operation principle of magnetic technology results from the physics of the interaction between a magnetic field and a moving electrical charge, in this case in the form of an ion. The magnetic field extends a force on the ions. The forces on ions of opposite charges are in opposite directions. The redirection of the particles leads to an increase of the frequency of ions of opposite charge colliding and combining to form a mineral precipitate. Since the reaction takes place at a low temperature (cooling water temp range) the scale or precipitate formed is non-adherent, i.e., does not stick to the heat exchanger surface.

The field experience accorded to the above-cited article is generally positive. Scale formation is dramatically reduced, and in some cases chemical scale control has no longer been required. The only case where efficiency has been limited is where the silica and/or iron content in water have been high. If silica and iron content in the water supply is low magnetic water conditioning should have a potential for the site. The magnetic water conditioner (permanent magnets) must be installed up stream of every single heat exchanger to be efficient. The installation is simple as the magnets are clamped on the outside of the pipe, and there is no 
requirement for electrical connection as permanent magnets are used. The magnets come in pairs and the vendor budgetary price per pair of magnets and number of pairs required per pipe size is listed in Table 7.

Even though the make-up water quality for this site was considerably low in iron and silica content, the cost for the magnets seems fairly high. It should be noted that the figures were only for a budgetary estimate. Whether magnets for scale control are cost-effective can also be judged when the investment cost is compared with the present cost for maintenance and scale control. The annual saving of USD 26,700 was estimated for a medium size cooling water system for duration from 1996 to 2002 (Hashim, 2004). Cost savings related to the ECWS by improving heat transfer is probably more difficult to estimate.

Table 7. Vendor budgetary prices (Hashim, 2004)

\begin{tabular}{|c|c|c|}
\hline No. of pipe & $\begin{array}{l}\text { No. pair } \\
\text { (device) }\end{array}$ & $\begin{array}{c}\text { Budgetary } \\
\text { price in USD }\end{array}$ \\
\hline 10 Nos of $1 \frac{1 / 2 "}{}$ & 1 & 4,500 \\
\hline 1 No of $2 "$ & 1 & 4,500 \\
\hline 1 No of $3^{\prime \prime}$ & 1 & 4,500 \\
\hline 2 Nos of $4 "$ & 2 & 9,000 \\
\hline 11 Nos of $6 "$ & 3 & 18,000 \\
\hline 3 Nos of $8 ”$ & 4 & 27,000 \\
\hline 3 Nos of $10 "$ & 5 & 27,000 \\
\hline 2 Nos of $12 "$ & 6 & 27,000 \\
\hline 4 Nos of $14 "$ & 7 & 27,000 \\
\hline 1 Nos of $36 "$ & 8 & 27,000 \\
\hline
\end{tabular}

The only recommendation based on this preliminary study is to conduct a plant trial on this technology for one of major heat exchangers requiring frequent cleaning due to scaling. This recommendation has been highlighted to management for consideration.

\section{Case study 2 - Upgrade the plant to latest design technology}

The newest oil operating facilities design concept should be incorporated with energy and water conservation initiatives. The facilities designs should be more environments friendly, which consistent with current business trends (Invista, 2009). One of main expectations is to design with minimum cooling load through comprehensive heat and water integration approaches.
As a good example is new Purified Terephthalic Acid (PTA) process technology. It has been considered one of energy and water intensive processes due to high water and energy intensity (Hashim, 2004). PTA reactors generate heat which has to been cooled down to meet the process requirement. In the old design, a large cooling water system was required to dissipate the heat from the plant.

With comprehensive process design changes such as lower down oxidation and purification reactors operating temperature, heat and water integration, the cooling load has been tremendously reduced. Cooling water consumption is believed to be $60 \%$ lower than a conventional PTA plant (Carrato, 2017; Invista, 2009). Subsequently, new PTA technology contributes an overall reduction in cooling load, with lesser hydraulic and organic loading to the effluent treatment plant.

\section{Case study 3 - Reuse final Effluent discharge}

One of the cooling water saving initiatives is to reuse effluent water as the cooling water make up. Brainstorming sessions were conducted at an anonymous plant with participants from technical as well as the plant operation team (Hashim, 2004). The team has identified the subject "Cooling water systems savings through water recycling options from operating facilities" as one of initiatives for technology evaluation study. The main objective was to reduce overall plant cost by minimizing the intake of treated water from a seawater desalination plant.

Effluent discharged from the oil operating facility is generated from multiple units and different applications. Effluent quality may vary depending on the type of contaminants or pollutants. Treating the effluent with customized technologies can make recycling options possible. In addition, matching the technology of plant effluent for the right plant application is the best approach to optimize the value of investment.

As reuse of plant effluent is a more long-term goal, the resources were more focused on short-term gains hence this study can only be considered as preliminary. Based on preliminary study, the proposed treatment of granular activated carbon (GAC) filter and microfiltration (MF) produce pre-treated recycle water from industrial that meets the specification of service water. This water quality can be 
used as make-up for open recirculation cooling tower and fire water system. It is noted significant saving of make-up cost with the estimated internal rate of return (IRR) over 30\% (Hashim, 2004). However, this treated effluent water has to be pre-conditioned to increase hardness prior to satisfy the cooling water chemicals program.

\section{Case study 4 - Blowdown improvement}

The objective of the study was to increased cooling water cycle by blowdown improvement. This study responded to the anonymous facility effort to reduce freshwater intake (Hashim, 2004). The controlling factor for the number of cycles or the amount blowdown is chloride content. In addition to chloride content in make-up water sodium hypochlorite is used as a disinfectant/biocide, which in practice doubles the chloride load of the system. Chloride content at this facility make-up water was about 8 to $10 \mathrm{mg} / \mathrm{l}$ which should mean that 25 cycles should be possible theoretically. In practice, the system was running with around 9 - 12 cycles because of this additional chloride load. If the chloride load could be reduced the number of cycles could be increased and water saved.

Chloride free alternative disinfectants are ultraviolet (UV) and ozone. As the purpose of this study was to reduce or rather replace chloride chemicals no further work was put into for any other options. Two vendors were contacted and offered both UV and ozone technology. Both vendors claimed that UV was not suitable due to the size and application in ECWS.

An example of the ozone process sketch is illustrated in Figure 4. The ozone system utilizes pure oxygen as feed gas. Ozone is injected via a pump and venturi combination into a side stream of cooling water supply line. The ozonized water will be introduced into the cooling water supply line. Ozone is a very powerful disinfectant, and biocide leaves no toxic reduces in the water.

The feed gas to ozonization crosses the ozoniser through the annular thin spaces between the dielectric tubes, as well the space between the high voltage (HV) electrodes and dielectrics. The HV-electrodes are maintained at high voltage, and the vessel is connected to the earth. The high electric field in the two annular spaces produces a silent electrical discharge (cold plasma) from the oxygen content in the ozone's feed gas. A part of the electric energy necessary for this ozone generation is transformed into heat. Heat is removed by cooling water passing through the vessel. Removing heat is necessary as ozone is destroyed by high temperature.

Cooling towers

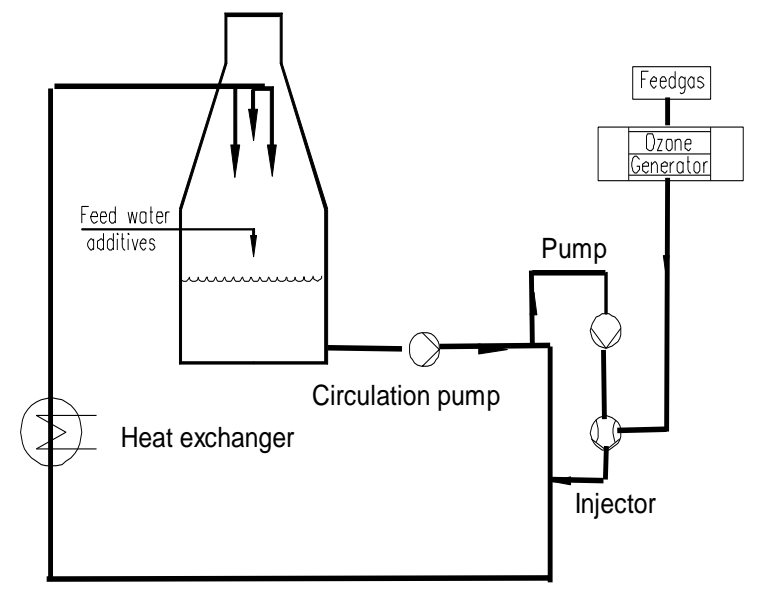

Figure 4. Example of process sketch

The drawback of ozone compared to chlorine is its short lifetime meaning that there is no residual concentration giving a long term effect. Ozone can fully replace sodium hypochlorite or chlorine, but the system might depend on site specific condition. It could need a dosage of oxidizing and non-oxidizing biocide to control bacterial growth in the system. The vendor claims that some systems can manage without any further biocide addition, while other systems still might need intermittent biocide injection.

In the cost estimate of the ozone system into three different options for biocide usage (no dosage, half dosage of present and as present) have therefore been calculated. The cost estimated based on a rented system for oxygen supply with $40 \mathrm{~m} 3$ storage tank for liquid oxygen and vaporizer, charging per cubic meter a fixed amount. Additional required installations were estimated for total CAPEX and OPEX. The full ozone system saves chemicals and reduces blowdown, but at the present cost for water, the payback period for an ozone system is about 9 - $\mathbf{1 1}$ years.

The environmental benefit of ozone compared to usage chlorinated compounds should also be considered. Other biocides have to be replaced at intervals, as the microorganisms adapt to it. This is not the case with ozone, which ensures high bacteriological quality at all times, 
provided that the cooling system has no deposits in the distribution system which can serve as breeding grounds for bacteria.

Legionella has been brought up as an issue for cooling towers located in certain climatic conditions. With high humidity and high temperature $\left(28-35^{\circ} \mathrm{C}\right)$ very favourable for the growth of Legionella bacteria, stringent bacteria control is required. Not all biocides are suitable for Legionella control, therefore, ozone is an effective alternative.

\section{Case study 5 - Cooling water systems improvement success story}

This case study is an example of a successful improvement in optimizing an ECWS (Hashim, 2004) at an oil facility. Operating cost was reduced after implementing cooling a water improvement framework. An improvement framework was started and followed by the formation of a focus team led by competent utility engineer. The team consists of multidisciplinary under the close supervision of top management (Hashim, 2004).

With clear vision and creation of objective and targets, the team then visited a top ranking facility to benchmark on ECWS performance. The main purpose was to learn how that facility managed to be in the top quartile. Several lessons learned were captured and evaluated for suitability, including technical, maintenance, operational, safety and environment, as well as potential savings.

The selected initiatives were implemented, with over $\$ 1$ million in annual energy savings. The saving could be much higher if cost avoidance (from a reliability perspective) were included. The initiatives implemented:

- Stopped one cooling water recirculation pump, and operated with four instead of five. This action resulted in over $\$ 1$ million in annual energy savings.

- Retrofitted initiative by replacing cooling tower fans with lighter blades. This initiative was implemented in accordance with a planned replacement schedule.

- Working with vendor to find the most suitable chemical treatment program. A customized treatment program was successfully tested and introduced on site. This program managed to minimize deposits and anti-scaling prior to operating at a reduced cooling water flow, with a high cooling water temperature, as well as low tower blowdown.

- Amended the dosing strategy for oxidizing and nonoxidizing biocide. It resulted in significant improvement in microorganism control.

- Optimized the operating mode of side stream filter and link to water quality.

- Established skill block path to enhance competency of utility operational, maintenance as well as technical teams.

- Introduced a simple laboratory test for critical parameters and performed by operators instead of chemicals treatment vendor. This enhanced ownership and control of the system.

- Identified a cooling system operators routine site visit checklist for tower internal and external condition, water leak, forming, process leakages, odours and other regular observations.

- Established cooling water network chart in distributed control system (DCS) with flow rate, temperature profile and efficiency.

- Tracked critical exchangers' performance such as velocity, exchanger heat balance, overall heat coefficient, skin temperature profile, fouling and corrosion monitoring.

- Conducted regular cooling tower basin' desludging and system cleaning as part of efforts to reduce chemical usage.

- Introduced simple cooling water optimized operating envelop on DCS screen with advisory alert for operator manual adjustment.

- Established an emergency scenario for the cooling system i.e., poor make-up water quality, plume, forming, loss water supply loss, process leakages, low make-up water harness, a lack of chemical treatment materials, and other potential cases.

The above initiatives were successfully implemented and transformed this company into the first quartile in energy performance in its sector. Subsequently, the revised biocide dosing and pre-cleaning strategy improved the reliability of heat exchangers by addressing major corrosion and fouling issues. 
6. Case study 6-Define design premises of cooling water systems

The intent of this case study was to ensure cooling system related best practices to be considered for new projects. As previously indicated, the involvement of competent utility engineers in the early stages of the design project is crucial to ensure cooling water design premises are fully evaluated. The improvement of major cooling water systems initiatives items for consideration include:

- Selection of cooling systems should not focus only on process requirement and CAPEX. Other factors should be considered such as quality and availability of make-up water, environment discharge limits, flexibility and OPEX (Bahadori, 2016).

- The cooling tower should be kept at a distance from the main operating plants to eliminate the contamination. Emitted carbon dioxide, sulphur dioxide, nitrogen dioxide or hydrocarbon gases can badly affect its water chemistry. It will result in poor cooling water performance and high OPEX. The project designer shall conduct a life cycle analysis by considering OPEX and environmental impacts prior to setting the tower location (Bahadori, 2016).

- Selection for cooling tower type either cross flow or counter flow or event induced or forced draft. The counter-flow tower is the best option to be considered due to its efficiency. The tower is also less likely to face biological attack and minimizes dirt scrubbing (Betz Industrial, 1989).

- Consider certain types of screens for location prone to sand and dust storms, to minimize the impact on cooling water quality (Freedman et al., 2004).

- Make-up water quality is always important to ensure the effectiveness of any chemicals treatment program. In some cases, pre-treatment of the incoming is necessary to remove solids content as well as for $\mathrm{pH}$ and water hardness correction to meet certain chemical treatment program requirements (Kemmer, 1987).

- The cooling water circulation pumps should be equipped with an inlet strainer to avoid impeller damage and to prevent the heat exchangers from getting plugged due to objects carry over (Prasad et al., 2005).
- Pumps should be equipped with energy efficient motor and VSD to make room for future flexibility (Ramasamy, 2016).

- Dedicated cooling water pumps for major users. Those at high elevation should be considered for future improvement of cooling water hydraulics.

- Cooling water fans should be equipped with VSD for energy improvement. Energy efficiency fan blades and motor should be selected for energy savings (Ramasamy, 2016).

- Cooling water blowdown should be on the return line and equipped with a flow meter and control valve for an adjustment (Freedman et al., 2004).

- Special study shall be conducted in collaboration with the chemical treatment vendor to determine the right treatment program and decide the chemicals dosing skid design (Richarson, 2014).

- Type of biocide dosing shall be decided based on the process requirement, OPEX, and environment constraints (Betz Industrial, 1989).

- Several test heat exchangers and slots for testing coupons shall be included for tracking cooling water performance (Kemmer, 1987)

- Include critical measurements: flow rate for cooling water circulation, make-up water, blowdown, temperature probe for supply and cooling water return, and critical heat exchangers, a power meter for pumps and fans, analysers for $\mathrm{pH}$, conductivity, turbidity, free chlorine and total organic carbon (Kemmer, 1987).

- The facility should consider removing any sludge that accumulates at the bottom of the cooling tower basin should be considered (Freedman et al., 2004).

- Blowdown shall be treated prior discharges to water body (General EHS Guidelines, 2020).

These items have been included in design by one of oil company. Each item shall be considered and strong justification required for not completing the item.

\section{CONCLUSION}

A successful cooling water improvement framework shall be established based on structured steps. This is a starting point to enhance cooling water systems performance at any 
concerned oil company, which also deem fit to be applied in any other interested company.

There are five main deployment steps and 16 sub-steps that shall be taken prior to strengthening the model. The first approach is to identify and follow by assessing and prioritizing cooling water improvement initiatives. Therefore, implementation of any accepted initiatives shall be planned in due course. Each of the implemented initiatives shall be closely monitored and evaluated to confirm its effectiveness. Lessons learned shall be compiled and reported to management for further review.
The proposed heuristic improvement framework has been established based on the industry best practices as some of the listed initiatives were based on real applications, as indicated in five case studies. The paper has also proposed a list of designs for cooling water systems, in particular ECWS as a preferred system in many oil companies.

\section{ACKNOWLEDGEMENT}

The authors acknowledge the several anonymous multinational oil companies for their cooling water systems improvement approaches used in this study.

\section{REFERENCES}

Australia Government 2013, 'Energy savings measurement guide: how to estimate, measure, evaluate and track energy efficiency opportunities', Department of Resources, Energy and Tourism Version 2, Australia.

Bahadori, A 2016, Essentials of oil and gas utilities: process design, equipment and operations, 1st edn, Gulf Professional Publishing, UK.

Bloch, HP 2016, Monitor equipment condition by collecting vibration signatures, Hydrocarbon Processing Magazine, Gulf Energy Information, Huoston, US.

Betz Industrial 1989, Cooling system mechanics, Industrial

Water Treatment Seminar, 2-3 November 1989, Beach Cove Clarion, Myrtle Beach, SC, US.

Capehart, BL, Turner, WC \& Kennedy, WJ 2012, Guide to energy management, 7 th edn, The Fairmont Press, Georgia, US.

Carrato, C 2017, 'Review environmental economic policy', Oxford Academic, vol. 11, no. 2, pp. 181-182.

Grossmann, IE \& Fuman, KC 2009, Challenges in enterprise wide optimization for the process industries, 1st edn, Springer, US.

General EHS Guidelines 2020, $<$ https://www.ifc.org/wps/wcm/connect/topics_ext_cont ent/ifc_external_corporate_site/sustainability-atifc/policies-standards/ehs-guidelines>.

Freedman, AJ, Krisher, AS \& Steinmeyer, D 2004, Guidelines for troubleshooting water cooled heat exchangers, Materials Technology Institute Incorporated, Missouri, US.
Hashim, MK 2004, 'Water management study for BP chemicals (m) sdn bhd.', MSc. thesis, Universiti Teknologi Malaysia, Johor, Malaysia.

Ng, DK \& Hassim, MH 2018, 'Identify energy savings opportunities from operational "self-help "and "quick fix" optimization approaches', Journal of Energy and Safety Technology (JEST), vol. 1, no. 2, pp. 41-49.

Hashim KM \& Ng, DKS 2019, 'A leading indicator to track status of energy management systems implementation', in 2019 Associate Energy Engineers (AEE) World Conference Proceedings, Washington, US.

Hansen, S and Brown WJ 2003, Making smart energy choices, Investment Grade Energy Audit, The Fairmont Press, Inc, Georgia, US.

Invista 2009, Project 10920, Technical Proposal for PTA plant, Invista Performance Technologies.

IPIECA 2013, 'Saving energy in the oil and gas industry', in The global oil and gas association for environment and social issues: climate change, International Association of Oil and Gas Producers, London, UK.

ISO 50001 2018, Energy management systems requirements with guidance for use, International Standards Organization, Switzerland.

Kaufman, AR 2012, Strategic planning plus, An organization guide, 1st edn, Sage Publications, California, US.

Kemmer FN 1987, The Nalco water handbook, 2nd edn, Nalco Chemical Company, McGraw Hill Book Company, US. 
Lattemann, S \& Höpner, T 2008, 'Environmental impact and impact assessment of seawater desalination', Desalination, vol. 220, no. 1-3, pp. 1-15.

Lindberg, CF, Tan, S, Yan, J \& Starfelt, F 2015, 'Key performance indicators improve industrial performance', Energy Procedia, vol. 75, pp. 1785-1790.

Liu, DHF \& Liptak, BG 1997, Environmental engineers' handbook, 2nd edn, Lewis Publishers, US.

Muller, MR, Muller, MB \& Rao, P 2013, 'Optimize energy use in industrial cooling systems', Chemical Engineering Progress, vol. 109, no. 11, pp. 18-23.

Prasad, V, Osborn, MD, Au, SS, Reddy, KRC., Shah, SS, Vora, NP \& Gryscavage, A 2005, 'Predictive heat exchanger efficiency monitoring, in Heat Transfer Summer Conference, January 2005, California, US.

Pyzdek, T \& Keller, P 2013, Handbook for quality management: a complete guide to operational excellence, 2nd edn, McGraw-Hill Education, New York, US.

Richardson, K 2014, 'Managing aging plants', Chemical Engineering Progress, vol. 110, no. 10, pp. 23.

Ramasamy, G 2016, 'Electric motor and energy management', Jurutera Journal, pp. 15.

Teicholz, IE 2001, Facility design and management handbook, McGraw-Hill Companies, New York, US.

Turner, CW 2011, 'Energy engineering', Journal of the Association of Energy Engineer, vol. 108, no. 5.

The National 2015, Saudi Arabia considers cutting energy subsidies to manage budget deficit, <https://www.thenationalnews.com/business/saudiarabia-considers-cutting-energy-subsidies-to-managebudget-deficit-1.12285>.

Turner, CW 2001, Energy management handbook, 4th edn, The Fairmont Press, Georgia, US.

US Department of Environment 2020, $<$ https://gmxinternational.com/downloads/pdf/Federal_ Technology_Alert.pdf $>$.

Worell E \& Galitsky, C 2005, 'Energy efficiency improvement in the petroleum refining industry', in Advisory Committee on Energy Efficiency (ACEE) Summer Study Energy on Efficiency in Industry, International Electrotechnical Commission (IEC), Geneva, Switzerland.

Worland, J 2015, What to know about the historic 'Paris agreement' on climate change, $<$ https://time.com/4146764/paris-agreement-climatecop-21/>.

Zandi C \& Nava R 2019, Rethinking water management, Bain and
$<$ https://www.bain.com/insights/rethinking-watermanagement-in-oil-and-gas/>. 